\title{
A Study on Translation Strategies used in Visayan Folktales
}

\author{
Jemma Victoria S. Enriquez \\ Department of Communications, Linguistics, and Literature, University of San Carlos, Cebu City, \\ PHILIPPINES \\ (iD) 0000-0003-2030-6237 \\ jvs.enriquez@gmail.com
}

ARTICLE INFO

Received: 14 December 2018

Accepted: 21 February 2019

Published: 8 May 2019

DOI: https://doi.org/10.29333/ojemt/5763

ABSTRACT

This research paper focused on observing and analyzing the translation strategies utilized in translating Visayan folktales into English. The researcher aimed to analyze whether the translation strategies utilized in the translations of the selected Visayan folklores were still able to deliver the ideas found in the important lines as well as the message of the story. The purpose of this study was to gain further understanding as to which translation strategies were more evident in literary works. 3 (three) folktales rendered in Bisaya and were translated in English served as the research data for this study. The researcher read and compared the Visayan versions with their corresponding English translations in word, sentence, and textual level in order to identify the translation strategies which were employed. The results showed that the use of the oblique translation method was more evident. Among the seven sub-categories of an oblique translation, the translated versions exhibited the frequent use of borrowing, transposition, and adaptation. The evident use of an oblique translation was reflected by the type of text that was translated. The translation strategies used in the English versions were still able to relay the similar message that the Visayan version of the folktales contained.

Keywords: translation, translation studies, translation strategies, Cebuano, Visayan folktales

\section{INTRODUCTION}

With over 1,707 islands comprising the Philippine archipelago, the Philippines inevitably houses more than 170 languages. In Region 7, the Central Visayas region, Cebuano Bisaya is the native language while English is the region's second language as it thrives in communicating to various clients or target market in fields such as business, academics, and even in everyday transactions (Solon-Villaneza, 2015).

Folklore is a part of a community's culture which is a depiction of the beliefs and lifestyle of the ancestors of that particular ethnic group. The retelling of these beliefs and practices are also created unique to that group. Oral traditions such as tales, proverbs, and jokes embody the various customs, the forms and rituals of celebrations such as Christmas and weddings, folk dances and initiation rites. Other aspects which are connected to what is being told in folklore are concrete materials such as traditional building styles and even handmade toys which are familiar to the communities which 
share these stories. Through the continuous sharing of folklore, these materials are also being handed down from previous generations to the present ones. These are part of tradition through verbal instruction or even through demonstration.

Oral traditions like these are very common among the indigenous tribes which are still existent in the Philippines. Philippine folktales translated to English were probably even used by American Teachers during the early 1900s when they were imparting their knowledge on the English language to Danawanon kids (Featuring Old Bisayan Folk Stories with English Translation, 2006). Additionally, Solon-Villaneza (2015) mentioned the need for including a secondary language in learning and appreciating more of the literary resources produced in the mother-tongue which paves way for the use of the English translations of these Cebuano Bisaya literary works. These resources rendered in Cebuano Bisaya will not only gain interest from native speakers of the language, but also to a global audience. As for how Visayan folktales also reflect a part of the Cebuano culture, having them translated to another target language (English) enables another audience to access a part of the source culture (Cebuano). Thus, this connection applicable through translation makes is essential for the translator to be familiar or knowledgeable as well of the cultural aspects and symbolic representations (aside from the language systems) present in the source culture to ensure that the purpose of the text will be carried over to the target audience.

This study aimed to look into the translation strategies used in the English-translated versions of selected Visayan folktales through observing and analyzing the patterns which can be found in the research data. The purpose of this study was also to further gain more understanding as to which translation strategies are more evident in literary works. Moreover, the researcher aimed to analyze whether the translation strategies utilized in the translated versions of the selected Visayan folklores were still able to deliver the idea in the important lines as well as the message of the story. The translation strategies used as the basis for the analysis of this research paper are the classification of translation strategies listed according to Vinay and Darbelnet (1958, cited in Owji, 2013).

\section{LITERATURE REVIEW}

Definition of Translation

Translation is defined to be used in order to transfer written or spoken SL (source language) texts into its equivalent texts in TL (target language), whether written or spoken. The purpose of translation, as discussed by Ordudari (2007), is to reproduce different kinds of texts from various fields to another language, making them more accessible to a bigger audience. Bai (2018) defined translation as a 'bridge of intercultural exchange' where it serves as a 'cultural translation', and not mainly a 'language translation'. Being able to understand and reflect the cultural significance of how certain items are expressed in the target language relays a message that becomes more appreciated by the receivers from the target community. Communicating cross-culturally through other resources is inevitable nowadays. This is one point which relates to how translators pose an important role in our society, serving as a 'bridge between two cultures and ensuring the successful communication between the two sides' (Shi, 2013).

\section{Translation Strategies}

Strategy, defined, refers to 'a planned, deliberate, goal-oriented procedure achieved with a sequence of steps subject to monitoring and modification' (Curriculum Learning Literate-Futures Glossary, cited in Owji, 2013). Another definition of strategy is the skill or art of devising or employing plans toward a goal (Merriam-Webster's dictionary, n.d.). 
Venuti (cited in Ordudari, 2007) defined translation strategies to 'involve the basic tasks of choosing the foreign text to be translated and developing a method to translate it'. With this definition, the concepts of domesticating and foreignizing are also put to use. In other words, a strategy is to be utilized when someone (in this case, a translator) encounters a problem in translating texts. The strategy opted by the translator plays an important role in the process since it should be appropriate to the needs of the text and the purpose of translating it in the first place.

An additional point to this is that before assessing the type of strategy to be utilized, the translator should also be able to evaluate the problems which need to be addressed. These problems in translation could vary from the lexicon used to metaphorical expressions, and differences in terms of syntax. In an article by Owji (2013), he mentioned general characteristics of translation strategies according to Chesterman which are text manipulation, application to the process, goal-oriented, problem-centered, conscious application, and inter-subjectivity. With these characteristics, a process stated by Bergen (cited in Owji, 2013) is as follows: translators are to read and comprehend the text, then identify and analyze differences which can be found between the source text and target text, thereafter the appropriate strategies to be used are decided which then results to the production of the equivalent text in the target language.

In conducting research on how a translator's motivation or willingness to translate has an impact on his use of translation strategies, Amipoor and Ghoonsooly (2015) tackled on the link between the translation process and the psychological field with the use of the Think-Aloud protocol. Mentioned in the methodology of their research article, 31 strategies were identified and classified in seven sub-categories which were getting an idea, achieving the translation, modification, facing difficulty, understanding the meaning, translating, and achieving equivalence. These sub-categories were also divided into two categories of higher-order and lower-order processing strategies. Translation process strategies included in sub-categories vary from reading the whole text first, repeating words or sentences, asking questions directed to the teacher, and even dictionary use. Amipoor and Ghoonsooly's article showed results that a translator's choice of strategies does vary on the willingness of the translator to take on the task.

Ordudari (2007) mentioned in his article that translating culture-specific concepts and allusions appear to be one of the challenging tasks that a translator has to encounter. However, it was still mentioned that there are strategies which can aid in handling culture-specific concepts and allusion in translating texts. Ordudari (2007) also cited Newmark's (1988) identification of the methods of translation. There were 8 (eight) methods mentioned which include word-for-word translation, literal translation, faithful translation, semantic translation, adaptation, free translation, idiomatic translation, and communicative translation.

Bai (2018) identified 4 (four) types of translation strategies that were evident in his study on translation strategies of English movie titles. The translation strategies mentioned were literal translation, free translation, transliteration, and the use of other translation strategies such as combining or compiling them to create 'a better effect'. In translating English movie titles, the translator should consider factors in the source language, target language, and national culture in order for the translated movie titles to ensure effective cross-cultural communication to the target audience. In addition, Bai also stated 4 (four) principles in his analysis when it comes to translating English movie titles which include the faithful value, aesthetic value, commercial value, and focus on the art 
of the title. Each of these principles should work together in achieving the purpose of informing and attracting viewers.

In translation, Chesterman (cited in Owji, 2013) listed the usual changes which can be rendered by the translator which include a) words used in the source text, b) structure of the words used, and c) natural context of the source text. In addition to this, Chesterman provided a detailed categorization of local translation strategies into semantic, syntactic, and pragmatic changes. However, aside from other strategies that were reviewed, Owji (2013) also cited Baker's (1992) taxonomy on translation strategies which is mentioned to be used by professional translators in aiding them to manage problems encountered in translation, making it the most applicable set of translation strategies. These include 8 (eight) translation strategies which are translation by a more general word, translation by a more neutral/less expressive word, translation by cultural substitution, translation using a loan word or loan word plus explanation, translation by paraphrase using a related word, translation by paraphrase using unrelated words, translation by omission, and translation by illustration.

Venuti (cited in Owji, 2013) stated that in alignment with Vinay and Darbelnet (1958), there are two methods of translation which are the direct/literal translation and the oblique translation. In the case when the direct/literal translation method is not applicable in handling the source text, oblique translation can be used and it contains seven sub-categories which comprise of borrowing, calque, literal translation, transposition, modulation, equivalence, and adaptation. Borrowing refers to using terms which are in the source language in the translated text. In other words, the term or expression is reproduced as it is when the text is translated to the target language. Calque refers to when the term in the source language is borrowed and translated into the target language. The borrowed words are translated to the target language in a similar form to the term in the source language. Literal translation is used when the text is translated word-for-word while maintaining the appropriate idiomatic or grammatical equivalent in the target language. This can be used when the two languages involved contain similar and closely related cultural terms. Transposition refers to substituting the word class of a certain term to another with the meaning of the message still intact. Modulation involves changing the point of view or a semantic change. Equivalence is the use of different expressions to present a similar message. Lastly, adaptation refers to using the term in the target language which is more culturally-appropriate in the target community. This method presents familiarity and better comprehension of the target viewers (Mathieu, 2016).

\section{METHODOLOGY}

The selected data for this study were 3 (three) folktales documented in Bisaya and were also translated into English. The research data were collected from two websites which are the Southeast Asian Languages and Cultures website (http://www.seasite.niu.edu/) which featured Visayan folktales with their corresponding English translations in their 'Cebu and Central Visayas Culture' page and the Danao Association USA, Inc. website (https://www.dausa.org/) which collected old Visayan folktales with its translations in English from a compilation of Cebuano literatures from the University of San Carlos' Cebuano Studies in their 'Lindog Bisaya' page. The mentioned websites were chosen since Visayan folktales were presented along with their respective English translations, contrary to other sources which only provided the English translated versions. With the 3 (three) selected Visayan folktales, 2 (two) of them were gathered from the Danao 
Association USA, Inc. website and 1 (one) folktale from the Southeast Asian Languages and Cultures website. The selected Visayan folktales are entitled "The Santo Niño of Cebu", "Si Ilagpot, Ang Mapangahason, Ug Ang Isdang Walay Bukog" ("Ilagpot, The Adventurous Mouse, And The Boneless Fish"), and "Si Haring Wati" ("King Wati"). The authors, as well as the translators of these selected folktales, were not identified in the previously mentioned websites.

This study made use of a descriptive-qualitative design. For the analysis of the research data, the researcher read and compared the Visayan versions with their corresponding English translations in order to identify the translation strategies utilized. The analysis was conducted through observing the folktales in word, sentence and, textual level. Equivalence in word usage as well as how translation was done on a semantic level was also taken into consideration. Cebuano Bisaya - English dictionaries and resources were used during data analysis for additional insight and further clarifications. The selected Visayan folktales were numbered 1-3 for simpler referencing (refer to Appendix).

\section{RESULTS AND DISCUSSION}

For the results of this study, the English-translated versions of the selected Visayan folktales showed the use of an oblique translation method. Among the seven subcategories, the translated versions exhibited the frequent use of borrowing, transposition, and adaptation. For borrowing, this strategy involves using the source language terms as they are presented in the source text. Folktale 1 made use of the word 'palay' (rice) both in the Visayan and English versions.

Dakong katingalahan nga wala tuod langgam o manok nga miduol sa gibulad nga palay.

(Astonishingly, no bird or fowl came near the drying palay.)

In the use of transposition, another word class is replaced for a different one without altering the meaning of the message in the text. Folktale 1 contained the word ' $k u h a$ ' enclosed in double quotation marks in the Visayan version which translates to 'the fisherman's catch' which functions as a noun while the English translation enclosed the word 'caught' in double quotation marks for a translation of the term which then functions as a verb.

\section{Iyang nadamgohan nga ang iyang "kha" nga agipo niadtong adlawa nahimong estatwa sa usa ka matahum nga bata.}

(He dreamed that the firewood which he "caught" that morning had turned into a statue of a beautiful child.)

For adaptation, terms that are culturally equivalent in the target language are utilized instead of terms which are only familiar and commonly used in the source language. In using this translation strategy, Folktales 2 and 3 can be seen to employ this with terms of address such as 'bay' (a title used by males of the same age to each other) and 'Nyor' (the title of address for men of high position, a shortened version of 'senyor'). A character's name was also modified for better comprehension in the target language. In, Folktale 3, the name 'Pedro' is translated to the English name 'Peter'. While the Visayan version made use of a nickname, the English version chose to use the character's full name.

"Asa man mo, bay?" pangutana sa ukitan nga ilaga. 
("Where are you going, friends?" asked the curious mouse.)

"Maayong udto, 'Nyor," matod nila.

(“Good noon to you, Sir," they greeted him.)

"Dro, adtoon ta si Haring Wati ug tan-awon nato kon makaila pa ba siya nato."

("Peter, let's go see King Worm and find out if he still knows us.")

In addition, Folktale 1 also made use of adaptation by translating the term 'antinganting' (talisman or amulet) into a simple definition which is 'a thing of magic'.

"Kon tinuod man nga ikaw usa ka anting-anting, abir kon imo bang mabugaw ang mga langgam ug manok gikan sa gibulad nga palay."

("If you are indeed a thing of magic, let's see you keep the birds and the chickens away from this drying palay.")

In another focus, Folktale 1 and 2 contained some Visayan terms which cannot be literally translated into English or that these terms do not have their equivalents in the English vocabulary. The identified terms are 'abir' (particle used to incite a person to do something) and 'bida' (an exclamation of surprise, a shortened version of 'purbida').

"Kon tinuod man nga ikaw usa ka anting-anting, abir kon imo bang mabugaw ang mga langgam ug manok gikan sa gibulad nga palay.”

("If you are indeed a thing of magic, let's see you keep the birds and the chickens away from this drying palay.")

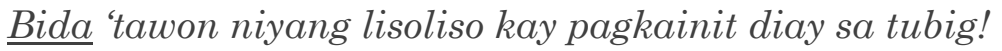

(What a time he had twisting and turning in the hot water!)

The rest of the translations of the selected Visayan folktales are rendered closely to their literal meanings in Cebuano Bisaya, following the correct English grammatical structure. It was also observed that the English-translated versions omitted to translate some vocabulary from the source language to the target language.

\section{CONCLUSION}

When translating literary works such as poems, fiction, or short stories, there is a challenge in fully committing to opt for a literal/direct translation. Moreover, when the two languages involved in the translation process are made up of different language systems and grammar structures, the translator will need to work with rendering an oblique translation in order to relay a close equivalent to the intended message of the source text.

In this study, the frequent use of borrowing, transposition, and adaptation was able to reflect the intended message that was contained in the Visayan versions of the chosen folktales. Since the research data used were folktales which would comprise of aspects of the Cebuano culture, strategies which could better transform and relay those concepts in a target language would be the ideal strategies. Despite other translation strategies also relating to the cultural factors found in the two languages involved, borrowing, transposition, and adaptation possess qualities which achieve the goal of letting both the 
source and target audiences gain interest and learn more about the languages and cultures of both sides. This finding goes back to the previously mentioned benefits and goals as to why translating literary works from a community's mother tongue to a secondary language is also essential. The effect of translation connects to various fields in the society which forms a relationship with everyone around the world.

For the recommendations of future research related to the topic in focus, other forms of literary works can be used for analysis such as essays and non-fiction. An additional factor to be included could also be the addition of a comparison with a third language alongside English like Tagalog or other languages from the Philippines. Since the authors and translators of the selected folktales analyzed in this study were unknown, future research could highlight literary works from a particular author translated into different languages by different translators or translated literary works from a specific translator to analyze whether a pattern can be identified. Using other frameworks for the taxonomy of translation strategies are also a recommendation for future research.

\section{REFERENCES}

Amipoor, F., \& Ghonsooly, B. (2015). Willingness to translate and its relation to translation strategies of MA university students. Translation Journal, 18(1).

Bai, Z. (2018). On translation strategies of English movie titles. Journal of Language Teaching and Research, 9(1), 119-124. https://doi.org/10.17507/jltr.0901.15

Cebuano and Visayan Folktales. (n.d.). Retrieved December 10, 2018, from Southeast Asian Languages and Cultures: Retrieved from http://www.seasite.niu.edu/tagalog/cebu\%20culture/cebu_folklore_fs.html

Featuring Old Bisayan Folk Stories with Engish Translation. (2006, January 28). Retrieved on December 10, 2018, from Danao Association USA, Inc.: https://www.dausa.org/2006/01/28/featuring-old-bisayan-folk-stories-with-englishtranslation/

Featuring Old Bisayan Folk Stories: SI HARING WATI (KING WORM). (2006, January 31). Retrieved from Danao Association USA, Inc.: http://www.dausa.org/2006/01/31/ featuring-old-bisayan-folk-stories-si-haring-wati-king-worm/

Introduction to Philippine Folklore. (n.d.). Retrieved on December 13, 2018, from http://folklore.philsites.net/index.html

Mathieu. (2016, January 21). 7 TRANSLATION TECHNIQUES TO FACILITATE YOUR WORK. Retrieved on December 13, 2018, from Cultures Connection: https://culturesconnection.com/7-translation-techniques/

Ordudari, M. (2007). Translation procedures, strategies and methods. Translation Journal, 11(3).

Owji, Z. (2013). Translation strategies: A review and comparison of theories. Translation Journal, 17(1).

Shi, X. (2014). Film title translation methods from the cultural difference aspects. Studies in Literature and Language, 8(2), 77-81.

Solon-Villaneza, K. (2015). Cebuano Visayan poetry: A study on translingual process. IAMURE Journal of Literature, Philosophy and Religion, 8. 


\section{APPENDIX}

\section{Folktale 1}

\section{The Santo Niño of Cebu}

Usa ka adlaw, ang usa ka kabus nga mangingisda sayo nga nanagat sagad sa iyang buhat matag adlaw. Apan niining adlawa hilabihan niya kadimalas kay matag buklad niya sa iyang baling wala siya'y laing kuha kondili usa ka agipo. Tulo ka beses nga gilabay sa mangingisda ang agipo balik ngadto sa dagat, apan matag bitad niya sa iyang baling ang maong agipo gihapon ang iyang kuha.

Sa iyang kasibot, bisan pa man sa iyang kalagot, gidala sa mangingisda ang gapnod nga kahoy sa iyang pagpauli. Pag-abut niya sa ila, iyang naabtan ang iyang asawa nga nagbulad sa palay sa ilang laguwerta. Giitsa sa mangingisda ang agipo ngadto sa palay dason hunghong sa kaugalingon, "Kon tinuod man nga ikaw usa ka anting-anting, abir kon imo bang mabugaw ang mga langgam ug manok gikan sa gibulad nga palay." Dakong katingalahan nga wala tuod langgam o manok nga miduol sa gibulad nga palay. Nianang pagkagabii, gidala sa mangingisda ang agipo sa sulod sa ilang balay ug kini iya rang nabiyaan sa buot.

Unya, nianang gabhiona, nakadamgo ug usa ka damgong katingalahan ang mangigisda. Iyang nadamgohan nga ang iyang "kuha" nga agipo niadtong adlawa nahimong estatuwa sa usa ka matahum nga bata. Uho na man, pagmata niya anang pagkabuntag, iyang nasaksihan ang usa ka katingalahan nga pagkabalhin. Ang agipo naporma ug ingon sa usa ka bata. Paglabay sa mga adlaw, ang porma sa bata nagakatinaw hangtud nga kini nahimong imahen sa Santo Niño nga sama sa atong makita karong panahona.

\section{The Santo Niño of Cebu (ENGLISH TRANSLATION)}

One day a poor fisherman went out early to the sea as usual. But the day turned out to be a very unlucky one for him because, every time he cast his net, all he would catch was a piece of firewood. Thrice the fisherman threw the firewood back to the sea; each time he pulled in his net, the same piece of firewood would turn up.

Disgusted yet fascinated by what had happened, the fisherman took the driftwood home with him. When he got home, he saw his wife drying palay on a mat out on their yard. The fisherman threw the firewood on top of the palay and muttered to himself, "If you are indeed a thing of magic, let's see you keep the birds and the chickens away from this drying palay." Astonishingly, no bird or fowl came near the drying palay. When evening came, the fisherman brought the piece of wood inside the house and forgot all about it.

But that very night, the fisherman had a strange dream. He dreamed that the firewood which he "caught" that morning had turned into a statue of a beautiful child. True enough, when he awoke in the morning, he saw a strange transformation happening before his eyes. The firewood had somehow taken on a form that looked like that of a little child. As the days went by, the child's features became clearer and clearer until at last it became the image of the Santo Niño as we would see it today. 
Folktale 2

Si Ilagpot, Ang Mapangahason, Ug Ang Isdang Walay Bukog

Sa Unang panahon, kaniadtong makasulti pa ang mga hayop, may usa ka ilagang mapangahason, si Ilagpot.

Usa ka buntag samtang nagsuroysuroy si Ilagpot sa daplin sa baybayon, nakakita siyag duha ka mangingisda nga mao pay pagpadulong sa lawod.

"Asa man mo, bay?" pangutana sa ukitan nga ilaga.

"Moadto mi sa lawod aron pagpangita sa isdang walay bukog," mitubag ang usa ka mangingisda nga mikidhat sa iyang kauban. "Lamian kayo ning isdaa kay wala may bukog," padayon niya.

"Motabang kog pangita, bi," matod ni Ilagpot.

"Nganong dili gud, basta may kaugalingon ka lang sakayan," tubag sa mangingisda.

Si Ilagpot midalig kuha ug bukong ug kahoy nga maoy iyang gihimong sakayan ug bugsay, unya miadto na siya sa lawod.

Didto sa lawod, gikahibalag niya ang malasugi.

"Asa ka man?" pangutana sa malasugi.

"Nangita ko sa isdang walay bukog."

"Ako diay?"

"Dili uy," nagpanglingo si Ilagpot. "Kadaghan nimog bukog, ah!"

Mipadayon ug bugsay si Ilagpot. Nakakaplag siyag lainlaing isda, apan walay usa kanila nga isdang walay bukog.

Sa kataposan, gikahibalag niya ang Kugita. Ang Kugita maoy isda nga ginapangita niya ug wala siya mag-usik ug panahon pagpahibalo sa iyang tuyo. Pagkahibalo sa Kugita niini, napungot siya, kay tiaw moy kan-on man diay siya ni Ilagpot. Mao nga gihulga 'pod niya si Ilagpot, mao nga midalidali siyag bugsay padulong sa baybayon. Wala 'gyod lungig gukod sa Kugita si Ilagpot. Pwerte gyong bugsay ni Ilagpot hangtod nahiabot sa baybayon.

Sa baybayon, may babaye diayng nagpabukal ug kinhason sa dakong kalaha. Sa pagdinalidali ni Ilagpot, giluksoan lang niya ang kalaha gikan sa bukong nga sakayan, ug mikaratil siyag dagan nga walay lingilingi.

Kaingon kaha sa Kugita nga si Ilagpot milukso sa sulod sa kalaha, mao nga milukso 'sad siya didto. Bida 'tawon niyang lisoliso kay pagkainit diay sa tubig! Hangtod nga nangulo-kulo ang iyang mga gaway. Pagkapula-pula na sa Kugita, giahon kini sa babaye uban ang kinhason kay tingpaniudto na man.

Ilagpot, The Adventurous Mouse, And The Boneless Fish (ENGLISH TRANSLATION)

A long time ago, when animals could still speak, there was an adventurous mouse called Ilagpot.

One morning while Ilagpot was walking along the seashore, he saw two fishermen who were just going out to sea.

"Where are you going, friends?" asked the curious mouse.

"We're going out to sea in order to find the boneless fish," answered one fisherman as he winked at his companion. "Boneless fish are delicious," he added.

"May I help you find him?" asked Ilagpot. 
"Why not, as long as you have your own boat," the fisherman answered.

Ilagpot immediately made a boat and a paddle out of a coconut husk and a stick. Then he went out to sea.

Once in the open sea, he met a swordfish. "Where are you going?" the swordfish asked.

"I'm looking for the boneless fish."

"How about me?"

"Oh, no" Ilagpot shook his head. "You have a lot of bones."

Ilagpot went on rowing. He met different kinds of fish, but not one of them was boneless.

At last, he met the Octopus. The Octopus was the fish that he had been looking for. He told the Octopus that he was after him. When the Octopus knew this, he got very angry, for it was no joke that Ilagpot wanted to eat him. So he threatened Ilagpot that he would drown him. Ilagpot trembling with fear hurriedly rowed toward the shore. The Octopus went after him. Ilagpot rowed as fast as he could until he reached the shore.

On shore, a woman was boiling seashells in a big pan. In his hurry, Ilagpot jumped over the pan from his boat of coconut husk, and ran as fast as he could without looking back.

The Octopus thought that Ilagpot had jumped into the pan, so he also jumped in. What a time he had twisting and turning in the hot water! At last, his tentacles curled. When the Octopus turned red, the woman scooped him out together with the seashells for it was already lunchtime. 
Folktale 3

Si Haring Wati

(Author Unknown)

Dugay nang nagpuyo si Haring Wati sa ilalom sa yuta, apan usa ka adlaw niana mihangyo siya sa atong Ginoo nga unta mahimo siyang tawo aron makaalagad sa mga kabos.

Unya, pagkahimo na niyang tawo, nadato siya.

Paglabay sa panahon, gitawag sa atong Ginoo si San Pedro ug miingon: "Dro, adtoon ta si Haring Wati ug tan-awon nato kon makaila pa ba siya nato." Tuod man giadto nila si Haring Wati, apan wala na siya makaila kanila.

Miingon ang atong Ginoo, "Paimna intawon kog tubig."

Gitawag ni Haring Wati ang iyang sulugoon ug nagkanayon: "Hoy, tagai na siyag imnonon sa manok."

Miinom lang usab ang atong Ginoo sa tubig. Pagkahuman, miingon siya kang San Pedro: "Dali, Dro, mamauli na lang ta, kay si Haring Wati wa na gyod makaila nato."

Namauli tuod sila ug nag-ilis ug maanindot nga sapot. Tingpaniudto na pagkabalik nila sa ka Haring Wati.

"Maayong udto, 'Nyor." matod nila.

Pagkakita ni Haring Wati sa maanindot nilang sapot, iya dayon silang gipasaka ug gipalingkod. Giingnan ni Haring wati ang iyang mga sulugoon sa pag-andam sa lamesa, unya gidapit ang atong Ginoo ug si San Pedro pagdungan ug paniudto kaniya.

Gihukas dayon sa atong Ginoo ang iyang amerikana ug gibutang duol sa kan-anan. Unya mao usab ang iyang gihimo sa iyang karsones ug sapatos, ug miingon siya: "Nan, amerikana ug sapatos ko, pangaon na lang mo kay kamo may gisilbihan ni Haring Wati."

Unya, giatubang sa atong Ginoo si Haring Wati ug miingon: "Haring Wati. mihangyo ka kanako nga unta mahimo kang tawo aron ikaw maoy magbuhi sa mga kabos. Apan tataw na kaayo nga dili gayud ikaw mohimo niana. Nan karon, balik ka sa yuta.”

Si Haring Wati miluhod sa atubangan sa atong Ginoo ug nangayog pasaylo. Apan wala gayud mabalhin ang hukom sa along Ginoo.

Mao nga karon ang Wati nahibalik sa iyang gigikanan, ug usahay gani ginatumban ra siya sa mga lumalabay nga gadanghag lang.

\section{KING WORM (ENGLISH TRANSLATION)}

King Worm had lived under the ground for a long time, but one day he begged our Lord to make him into a man. King Worm said he would like to take care of the poor.

When King Worm became a man, he became rich.

After a time, our Lord called St. Peter and said:

"Peter, let's go see King Worm and find out if he still knows us." So they went to see King Worm, but he didn't recognize them.

Our Lord said: "Please let me drink some water."

King Worm called his servant, saying: "Give him some of the water for the chicken."

Our Lord humbly drank the water. Then, he said to Peter: "Let's go home, for King Worm doesn't remember us anymore."

Then went home and changed into handsome clothes. It was lunchtime when they got back at King Worm's house. 
"Good noon to you, Sir," they greeted him.

Seeing their handsome clothes, King Worm immediately asked them to come up and sit down. He told his servants to prepare the table, then invited our Lord and St. Peter to lunch with him.

Our Lord immediately took off his coat, his trousers and shoes. He placed them on the floor near the table. Then, our Lord said to his clothes: "There, my coat and shoes, you may eat for it's you that King Worm is serving."

Then our Lord faced King Worm and said: "King Worm, you begged me to make you into a man so you could take care of the poor. But it's clear that you aren't doing what you promised me. So I shall send you back to the ground."

King Worm knelt before our Lord and asked for forgiveness. But our Lord did not change His Mind.

That is why the Earthworm is back where he came from, sometimes to be trampled upon by careless passers-by.

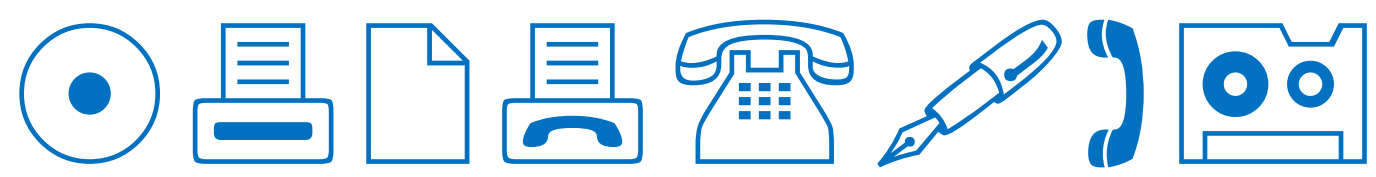

